I wish to thank Miss Theda Flint-Gallé and Mr. R. A. Simmonds for technical assistance.

C. H. Gallaghey

Division of Animal Health,

McMaster Laboratory,

Commonwealth Scientific and Industrial

Research Organization,

Glebe, New South Wales.

'Cleland, K. W., Nature, 170, 497 (1952).

${ }^{2}$ Slater, E. C., and Cleland, K. W., Nature, 170, 118 (1952).

${ }^{3}$ Raaflaub, J., Helv. Chim. Acta, 38, 27 (1955).

${ }^{4}$ Hunter, F. E., and Ford, L., J. Biol. Chem., 218, 357 (1955).

s Von Korff, R. W., Science, 126, 308 (1957).

'Lester, R. L., and Hatefy, Y., Biochim. Biophys. Acta, 29, 103 (1958)

${ }^{7}$ Christie, G. S., and Judah, J. D., Proc. Roy. Soc., B, 142, 241 (1954).

${ }^{8}$ Sehneider, W. C., J. Biol. Chem., 176, 259 (1948).

- Potter, V. R., Siekevitz, P., and Simonson, H. C., J. Biol. Chem. 205, 893 (ig53).

10 Siekevitz, P., Löw, H., Ernster, L., and Lindberg, O., Biochim. Biophys. Acta, 29, 378 (1958)

11 Recknagel, R. 0., and Anthony, D. D., Fed. Proc., 16, 105 (1957)

12 Recknagel, R. O., and Anthony, D. D., J. Biol. Chem., 234, 1052 (1959).

${ }^{23}$ Siekevitz, P., and Potter, V. R., Fed. Proc., 12, 267 (1953)

14 Potter, Y.R,. "Manometric Techniques", third ed., edit. by Umbreit, W. W. et al. 175 (Burgess Publishing Co. Minneapolis, 1957).

${ }^{15}$ Golby, R. L., Hildebrand, G. P., and Reilley, C. N., J. Lab. Clin. Med., 50, 498 (1957).

${ }^{10}$ Hunter, F. F., Malison, R., Bridgers, W. F., Schutz, B., and Atchison, A., J. Biol. Chem., 234, 698 (1959).

\section{Marked Humpback Whale of Known Age}

THE determination of age in humpback whales has been by indirect methods using baleen plates and ear plugs. By these methods, I found that humpback whales in Australian waters reach puberty between 3 and 7 years of age, the majority of puberal whales being 4 or 5 years ${ }^{1}$. Nishiwaki ${ }^{2}$, using the ear plugs from humpback whales taken in North Pacific waters, found that the average age at sexual maturity was 5 years.

Until recently it has not been possible to check these results by direct evidence from marked whales. Dawbin $^{3}$ obtrined some evidence from two humpback whales marked in New Zealand waters when at least 1 year old and recaptured after 12 and 19 months respectively. Since both were sexually immature when killed, Dawbin showed that the minimum age at sexual maturity was $3-4$ years. Ear plugs and baleen plates were collected from one of these whales, and the present methods of interpretation of these organs for age determination gave results consistent with the probable age of this individual.

Further information is now available from a humpback whale marked (Mark No. 11689) on October 6,1954 , at $27^{\circ} \mathrm{S}$. $1531^{\circ} \mathrm{E}$., when it was migrating southwards on the east coast of Australia. It was then recorded as a yearling approximately $30 \mathrm{ft}$. in length. This mark was recovered on August 26, 1959, from a male humpback shot at $25^{\circ} 21^{\prime} \mathrm{S}$. $112^{\circ} 26^{\prime} \mathrm{E}$. off the west coast of Australia.

As ear plugs, baleen plates, and testis weights were obtained from this specimen, it has been possible to compare the age estimated from these organs with the known minimum age. Following the method of interpretation of baleen traces described by $\mathrm{me}^{1}$, the age of this whale was determined as at least 5 years. The ear plugs contained 12 laminations, and, using the postulate of two laminations per year, the age of this whale was estimated at 6 years. Since the whale was at least at the beginning of its second year when marked, it was probably 6 years of age when shot. So the indirect methods using baleen plate traces and ear plug laminations give estimates of age in good agreement with the known age.

The testes each weighed $1.0 \mathrm{kgm}$., which indicates ${ }^{5}$ that this whale was sexually immature, and that puberty would probably have been attained at 7 years of age. This is above the age at which most male humpbacks have been estimated to reach puberty ; but it is not an isolated example since, of 118 males (from the west coast of Australia) the ear plugs of which contained 12 laminations, 6 per cent were still sexually immature.

The body-length of this whale was recorded as $36 \mathrm{ft} .9 \mathrm{in}$., which is relatively short for a male of 6 years but within the range of lengths recorded for males of that age. In 164 males from Australian whaling stations estimated on the evidence from ear plugs to be 6 years old, the body-lengths ranged from $34 \mathrm{ft} .7$ in. to $43 \mathrm{ft}$. 3 in. with a mean length of $39 \cdot 11 \mathrm{ft}$., standard deviation $1.62 \mathrm{ft}$., and a standard error of mean $0.13 \mathrm{ft}$. It is therefore probable that this was a slow-growing individual relatively late in maturing.

The recovery of this mark is also of interest because it is the first recovery on the west coast of a mark fired into a whale on the east coast of Australia. This change of migration path followed the mingling during the summer of 1958-59 of some of the group V $\left(130^{\circ}\right.$ E. $-170^{\circ}$ W. $)$ with the group IV $\left(70^{\circ}\right.$ E. $-130^{\circ}$ E.) dopulation of humpback whales which $I{ }^{4}$ have shown in the region of the Antaretic from $110^{\circ} \mathrm{E}$. to $130^{\circ} \mathrm{E}$.

\section{R. G. Chittueborough}

Division of Fisheries and Oceanography, Commonwealth Scientific and Industrial

Research Organization, Sydney, Australia. Jan. 14.

${ }^{1}$ Chittleborough, R. G., Aust. J. Mar. Fresh. Res., 10, 125 (1959). 2 Nishiwaki, M., Sci. Rep. Whales Res. Inst. Tokyo, 14, 49 (1959). ${ }^{3}$ Dawbin, W. H., Nature, 188, 1749 (1959).

4 Chittleborough, R. G., Norske Hvalfansttid, 48, 510 (1959).

${ }^{5}$ Chittleborough, R. G., Aust. J. Mar. Freshw. Res., 6, 1 (1955).

\section{Morphogenetics of Micrasterias americana in Clone Culture}

Waris, Grönblad and I have studied the plasmatic basis of the morphological units in Micrasterias species and their dependence on the nuclear influence ${ }^{1}$. The names of the morphological units and the schematically drawn plasmatic axes are shown in Fig. 1. The form, as well as the number, of the morphological units may be altered by a change in environmental conditions and by a change in the relative nuclear influence.

The concept 'nuclear effect per cytoplasmic unit' is of importance when variation in the morphology of the cell is considered. The variation can be induced artificially in different cell types (anucleate, hypohaploid, haploid, hyperhaploid, subdiploid and diploid cell types ; binucleate cells of different types, mononucleate double cells; uniradiate, triradiate and quadriradiate types). The degree of organization of the side lobes usually increases in parallel with an increase in nuclear quantity; but the polar lobe usually undergoes only slight modification.

Also the number of morphological units may increase with the nuclear quantity, whereupon 